\title{
Preparation of Pumpkin Pulp and Peel Flour and Study Their Impact in the Biscuit Industry
}

\author{
Shamaail A. Saewan Saher S. George \\ Department of Food science, College of Agriculture, University of Basrah, Basrah City, Iraq
}

\begin{abstract}
Pumpkin pulp and peels were processed into flour after drying each part separately. The two types of flour were analyzed for their proximate composition and functional properties. Ash, fat and carbohydrates contents in pulp and peel flour were not significantly different $(\mathrm{P}<0.05)$, in contrast, significant differences $(\mathrm{P}<0.05)$ in moisture and protein content were found in both types of flour. Pumpkin pulp flour and peel flour differed significantly ( $\mathrm{P}$ $<0.05$ ) in water absorption and oil binding. No significant difference was observed between two types of flour for swelling index. Biscuits prepared by replacement of wheat flour with pumpkin flour (pulp and peel) $(0 \%$, $3 \%, 6 \%, 9 \%$ and $12 \%$ ) were analyzed for their physical measurements and sensory evaluation. There was a slight significant decrease $(\mathrm{P}<0.05)$ in the mean diameter and thickness with increasing the ratio of pulp flour compared with the standard treatment $(0 \%)$, also, a significant increase was recorded in spread ratio by increasing ratio of replacing. There was a significant decrease $(\mathrm{P}<0.05)$ in mean diameter and spread ratio with increasing the replacement ratio of peel flour compared with standard treatment. The mean thickness increased by increasing the ratio of replacement compared with standard treatment and biscuit of pulp flour. Significant differences $(\mathrm{P}<0.05)$ were recorded for sensory characteristics such as appearance, color, odor, taste, texture and overall acceptability between biscuits. Biscuits with a replacement ratio of $3 \%$ of pulp and peel flour were the most acceptable for all sensory evaluation parameters. There was a slight significant decrease $(\mathrm{P}<0.05)$ for the previously mentioned sensory parameters among biscuits prepared with different ratios of pumpkin peel flour, the replacement ratio of $3 \%$ gave the highest mean values.
\end{abstract}

Keywords: Pumpkin flour, pumpkin composition, functional properties, biscuit, sensory evaluation, pumpkin biscuit, pumpkin pulp, pumpkin peel, physical properties, Spread ratio.

DOI: $10.7176 / \mathrm{JBAH} / 10-6-05$

Publication date:March $31^{\text {st }} 2020$

\section{Introduction}

Consumers tend to consume high nutritional value foods, even if they are not very popular. Vegetables offer a wide range of products in the marketplace, including pumpkins that have become increasingly popular recently. Until recently, pumpkins were usually considered to be an ornamental plant even though they have high nutritional value. Recently, pumpkins have become an essential ingredient in various meals (NawirskaOlszańska et al., 2011).Pumpkin (Cucurbita sp.) is one of the most important agricultural products. belonging to the Cucurbitaceae family, the latter of which is considered one of the largest families in the plant world. Pumpkins belong to three varieties pepo, moschata and maxima, which grow widely in tropical and subtropical regions around the world (Toan and Thuy, 2018).

Pumpkins importance as a food source for humans stems from its containing many important nutrients such as carbohydrates, trace minerals like zinc, pectin, dietary fibers, and vitamins such as tocopherol and B-carotene, the source of vitamin A, which gives the fruit its yellow color. Pumpkins also contain plant sterols, unsaturated fatty acids and antioxidants which are considered important to human health (Pongjanta et al., 2006; Pasha et al., 2013). Flesh is the most used part of pumpkin fruit; it can be used in food preparation (Mujaffar and Ramsumair, 2019). Plant peels can improve nutritional aspect of the food products because they are rich in fibers (Batista et $a l ., 2018$ ). Pumpkin seeds are eaten by many peoples, either raw or roasted; also they can be used in preparing salads and in baking industry as an ingredient of bread and cakes (Sathiya Mala et al., 2018).

The color of pumpkin flour may vary from dark yellow to orange. As a result of its color, good flavor, and sweet taste, pumpkin flour represents a major ingredient for use in the baking industry. This flour has a long shelf-life, which makes it suitable as a natural ingredient in many food products, such as pasta, instant noodles, sauces, spices and soups. Adding pumpkin flour helps to improve nutritional value, giving good color and high quality to many baked products. Therefore, using $5 \%$ of the pumpkin flour to such products should provide a good result (Pasha et al., 2013).

Biscuits are one of the most popular baked goods in the world. They are rich in carbohydrates, fat and energy, but their content of fibers, vitamins and minerals makes biscuits a non-integrated diet for daily use (Mishra and Chandra, 2012). In order to increase the nutritional value of some baked products like biscuits, cakes, cookies and pancakes and to improve their overall quality, it is achievable by adding pumpkin flour and fresh fruits to the mixture during the manufacturing process. Due to the increased demand of a large number of consumers for food products with high nutritional value and rich in fiber content and other components, this 
study considered preparing pumpkin flour from pulp and peel, and observing and analyzing its physicochemical and functional properties. The resulting flour was used with different concentrations to produce and assess biscuits.

\section{Materials and Methods}

\section{Preparing of Pumpkin Flour}

The study purchased fruits of pumpkin from Qarmat Ali local market in Basrah City, south of Iraq. They were prepared in accordance with the method outlined by Cerniauskiene et al., (2014). Ten ripe fruits were used with weights ranging from 2 to $3 \mathrm{~kg}$. They were washed initially with tap water, then with distilled water, and dried carefully thereafter. Following their cleaning, the pumpkin fruits were peeled and cut with sharp knives, fibers and seeds were removed, the pulp and peel were cut into pieces 2-3 mm thick, and finally, each sample was dried at $60^{\circ} \mathrm{C}$ in the laboratory drying oven (Heraeus- Germany). After this process, the samples were grinded and sifted using a fine sieve to obtain a very fine powder, and kept in freezer at a temperature of $-18 \pm 2{ }^{\circ} \mathrm{C}-$ after placing in sealed containers - until the required tests were performed.

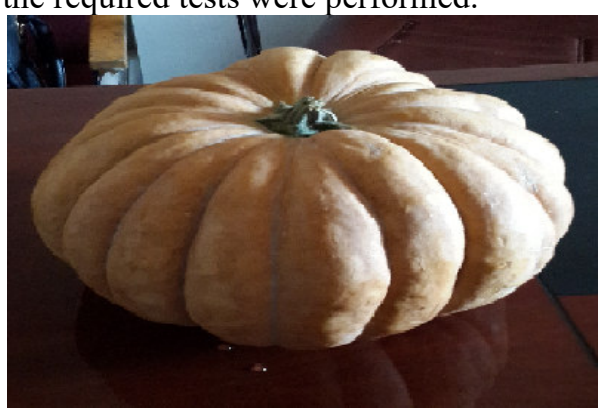

Fig. 1 Pumpkin fruit

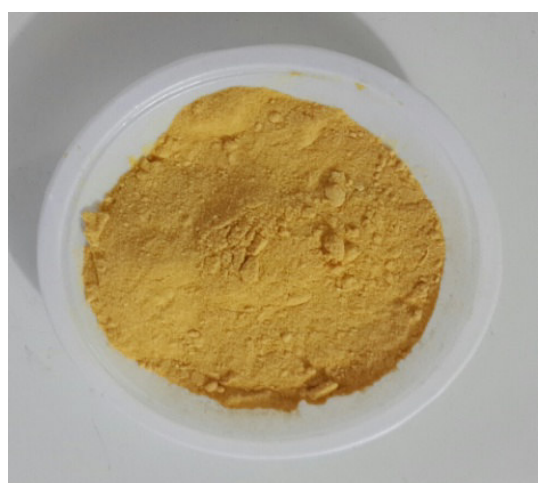

Fig. 2 Flour of pumpkin pulp

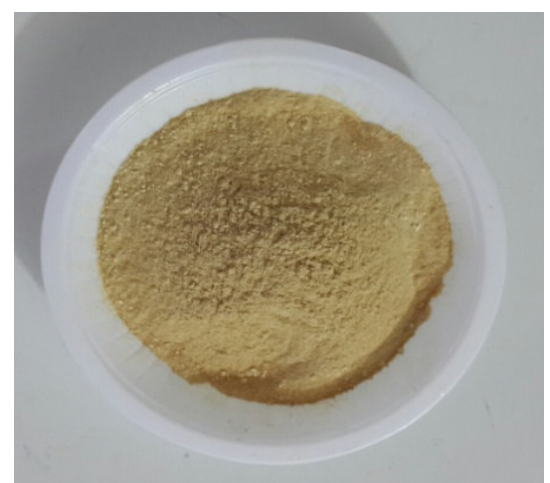

Fig. 3 Flour of pumpkin peel

\section{Proximate Analysis of Pumpkin Pulp and Peels Flour}

Moisture content and total ash were analyzed according to standard methods in AOAC (1984). Crude protein (\% Nitrogen $\times 6.25$ ) was performed using the procedure recommended by Pearson (1970). Crude fat was calculated as mentioned in AOAC (1975), while carbohydrate content was estimated by difference.

\section{Functional Properties of Pumpkin Pulp and Peels Flour}

Water absorption ability and oil binding capacity were measured as recommended in Beuchat (1977). Swelling characteristic was measured according to the procedure of Verma et al. (2014). $1 \mathrm{~g}$ of pumpkin flour was weighed and placed in to standard test tubes, then $25 \mathrm{ml}$ of distilled water was added and was shaken vigorously every 10 min for one hour, by vortex (VM-300- Taiwan). The sample was left to settle in the test tube for 24 hours at room temperature and then the final size of the swelling sample was measured, the swelling index calculated according to the following formula:

Swelling index $\%=\{($ final volume - primary volume $) /$ final volume $\} \times 100$

\section{Preparation of Biscuits}

Biscuits were prepared in accordance with the standard method in AACC (2000), with some modifications. The refined wheat flour was replaced with the pumpkin flour (pulp and peels) with 3\%, 6\%, 9\% and 12\% respectively. For each $100 \mathrm{~g}$ flour, $35 \mathrm{gm}$ of ground sugar, $20 \mathrm{~g}$ of shortening vegetable fat, $0.5 \mathrm{gm}$ of salt, $0.5 \mathrm{~g}$ of sodium bicarbonate, $1 \mathrm{gm}$ of baking powder and $2 \mathrm{gm}$ of powdered milk were add. The proportion of water 
was variable according to the ratio of pumpkin flour in the mixture. All solid components were sieved three times to ensure uniformity, then the shortening vegetable fat was added followed by water, the contents were mixed well to make the dough which was covered with a polyethylene, and kept in the refrigerator for half an hour. Following this procedure, the dough was sheeted by using a wooden rolling pin with a thickness of 2-3 $\mathrm{mm}$, then cut into circular biscuits of $6 \mathrm{~cm}$ diameter, and baked in oven at $180^{\circ} \mathrm{C}$ for $10-12$ minutes. A standard biscuit (control) was prepared by using all ingredients mentioned above except for the pumpkin flour $(0 \%$ pumpkin flour).

\section{Physical Properties of Biscuit}

The Physical measurements of biscuits (diameter, thickness and spread ratio were calculated as mentioned in AACC (1976). The diameter (D) of biscuits was calculated by laying six biscuits edge-to-edge then measuring to the nearest $\mathrm{mm}$. The thickness $(\mathrm{T})$ of the biscuits was measured by putting six pieces one above the other and the average value was calculated as $\mathrm{mm}$ by vernier. The spread ratio $(\mathrm{D} / \mathrm{T})$ was done by partitioning the average value of diameter (D) by the average value of thickness $(\mathrm{T})$ of biscuits.

\section{Sensory Evaluation of Biscuits:}

Biscuits were analyzed for sensory properties. Sensory quality characteristics were evaluated by a group of 10 panelists from department of food sciences, using a 9-point Hedonic scale (ranging from "like extremely" $=9$ to "dislike extremely" =1). The study also evaluated the biscuits for appearance, color, odor, taste, texture, and overall acceptability (watts et al., 1989).

\section{Statistical Analyses}

In the current study, the data were subjected to one-way analysis of variance (ANOVA) using XL Stat program for Windows. Differences between the means were tested by Duncan's multiple range tests. The level of significance was set at $\mathrm{P}<0.05$. The results are presented as means (Steel et al., 1996).

\section{Results and Discussion \\ Proximate Composition and Functional Properties}

Table 1 shows the mean concentration $(\%)$ of the proximate composition of pumpkin pulp and peel flour. No significant differences $(\mathrm{P}<0.05)$ were observed in ash, fat and carbohydrates concentrations between two types of flour, while concentrations of moisture and protein were differed significantly $(\mathrm{P}<0.05)$ for pumpkin pulp and peel flour.

The moisture, ash, protein, fat, and carbohydrates in pumpkin pulp flour formed $9.647 \%, 9.293 \%, 1.930 \%$, $2.343 \%$, and $76.793 \%$, respectively. These study results are similar and comparable to results reported in earlier studies conducted by others. For example, according to Roongruangsre and Bronlund (2016), they discovered that when pumpkin pulp was dried at $60^{\circ} \mathrm{C}$, the flour moisture content was $7.46 \%$. In addition, they found out that by increasing the temperature during the pumpkin dehydration process could reduce the moisture level and water activity of the pumpkin flour product. Application of these findings will improve significantly the quality of the flour product and increase its shelf life, as well. Low moisture content and low water activity are two vital factors having an impact on inactivation of enzymes during storage. This process may also have an impact on and possibly prevent non-enzymatic browning reactions, fat oxidation, and microbial growth.

Table 1. Proximate Composition of Pumpkin Pulp and Peel Flour

\begin{tabular}{|l|c|c|}
\hline Analyses (\%) & $\begin{array}{c}\text { Pumpkin Pulp Flour } \\
(\text { Mean +Standard Error) }\end{array}$ & $\begin{array}{c}\text { Pumpkin Peel Flour } \\
(\text { Mean }+ \text { Standard Error })\end{array}$ \\
\hline Moisture & $9.647 \pm 0.080^{\mathrm{a}}$ & $7.523 \pm 0.320^{\mathrm{b}}$ \\
\hline Ash & $9.293 \pm 0.160^{\mathrm{a}}$ & $9.570 \pm 0.325^{\mathrm{a}}$ \\
\hline Protein & $1.930 \pm 0.095^{\mathrm{b}}$ & $3.680 \pm 0.210^{\mathrm{a}}$ \\
\hline Fat & $2.343 \pm 0.595^{\mathrm{a}}$ & $3.533 \pm 0.240^{\mathrm{a}}$ \\
\hline Carbohydrates & $76.793 \pm 0.550^{\mathrm{a}}$ & $75.700 \pm 0.460^{\mathrm{a}}$ \\
\hline
\end{tabular}

All data are means of triplicate concentrations. Means with different letters are significantly different $(\mathrm{P}<0.05)$.

Further, pumpkin peel flour reportedly contained a moisture level of $7.523 \%$, ash at $9.570 \%$, protein at $3.680 \%$, fat at $3.533 \%$, and carbohydrates at $75.700 \%$. Staichok et al. (2016) found almost the same results as this study. The proximate composition of pumpkin peel flour in the mentioned study included a moisture level of $8.58 \%$, ash at $5.56 \%$, protein at $17.99 \%$, fat at $7.02 \%$, and finally carbohydrates at $61.85 \%$. In addition, Nyam et al. (2013) reported that their study's pumpkin peel flour had the following ingredient percentages: moisture at $5.96 \%$, fat at $5.77 \%$, protein at 23.89 , ash $0.41 \%$, and carbohydrate at $49.11 \%$. Researchers stated that pumpkin peel flour is a proper ingredient for use in the baking industry, especially for baking products low in fat and calories. It should be noted that "volatilization" a progression that could happen during chemical analysis of food could impact and result indifferences in the level of ash content in the original food specimen than the one 
analyzed (Pratyush et al. (2015).

Table 2 and figure 4 show mean values of some functional properties of pumpkin flour. Pumpkin peel flour differed significantly $(\mathrm{P}<0.05)$ with pumpkin pulp flour, and exhibited less water absorption capacity $(5 \mathrm{ml} / \mathrm{gm})$ compared with pumpkin pulp flour $(8 \mathrm{ml} / \mathrm{gm})$. Water absorption is an essential physiochemical and functional property of protein. It might have an enormous impact on food properties and a variety of things can happen during preparation, processing, and storage of food (Appiah et al., 2011). It can also affect its nutritional content. Water absorption is one of the vital properties of pumpkin flour that can enhance the possibility of using it as a thickener to fix liquid or semi-liquid food such as sauces and soups. Pumpkin contains a high percentage of insoluble fibers such as cellulose, hemi-cellulose, pectin and lignin, which all have a good capacity to absorb water. Therefore, using pumpkin flour will improve the stability of the food product. In addition, plant fibers contain more pectin, which make it more capable of linking water than fibers of grain (cereals) and legumes. Hydration properties depend on the chemical composition of food. The presence of hydrophilic pectin with side chains that lead to high water absorption and swelling. The high content of lignin produces hard and nonpermeable fibrous molecules (Păucean and Man, 2014).

Table 2. Functional Properties of Pumpkin Pulp and Peel Flour

\begin{tabular}{|l|c|c|}
\hline Functional properties & $\begin{array}{c}\text { Pumpkin Pulp Flour } \\
\text { (Mean +Standard Error) }\end{array}$ & $\begin{array}{c}\text { Pumpkin Peel Flour } \\
\text { (Mean +Standard Error) }\end{array}$ \\
\hline Water Absorption (ml water/gm) & $5.000 \pm 0.100^{\mathrm{b}}$ & $8.000 \pm 0.100^{\mathrm{a}}$ \\
\hline Swelling Index (\%) & $87.497 \pm 0.250^{\mathrm{a}}$ & $85.503 \pm 0.590^{\mathrm{a}}$ \\
\hline Oil Binding (ml oil/gm) & $1.500 \pm 0.050^{\mathrm{b}}$ & $1.997 \pm 0.005^{\mathrm{a}}$ \\
\hline
\end{tabular}

All data are means of triplicate measurements. Means with different letters are significantly different $(\mathrm{P}<0.05)$.

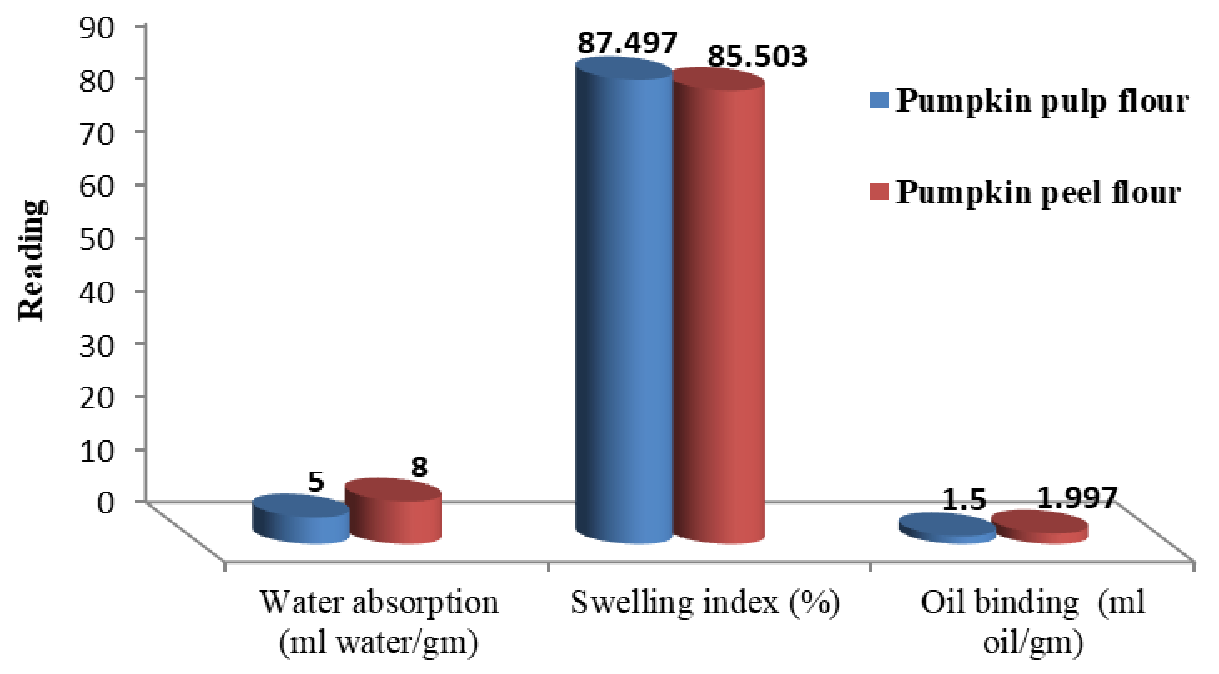

Functional Properties

Fig. 4. Functional Properties of Pumpkin Pulp and Peel Flour

The results didn't show significant differences $(\mathrm{P}<0.05)$ in swelling index. Pumpkin flour recorded a very good ability to swelling, $87.497 \%$ for pulp flour versus $85.503 \%$ for peel flour. There is an inverse relationship between fat fiber content and its ability to swelling. When fat is high the fiber loss ability to swell- the presence of fat within fibers- restricts water molecules from entering the sample and therefore decrease the swelling. In this study, both pulp and peel flour had a high capacity to swell because of the low content of fat. This caused water molecules to penetrate within fibers and increase swelling (Nyam et al., 2013).

For oil binding, the results showed significant differences $(\mathrm{P}<0.05)$ pulp flour bound $1.5 \mathrm{ml} / \mathrm{gm}$ as compared to peel flour, $1.997 \mathrm{ml} / \mathrm{gm}$. The high percentage of insoluble fibers in pumpkin peel flour as compared to pulp flour may be the reason for this phenomenon. This was recorded by Nyam et al. (2013), when they experimented with the ability of pumpkin seed and peel flour to bind oil. In addition, heat treatment enhances flour ability to bind oil, it seems that temperature of oven during drying process of pulp and peel increased the ability of pulp and peel flour to bind oil (Fagbemi et al., 2005). Researchers mentioned the above finding after they measured the ability of powder of boiled and roasted pumpkin seeds, the denaturation helped in deterioration the hydrophobicity of protein.

The functional properties; oil binding and water absorption of pumpkin powder are considered critical 
parameters in controlling the quality of bakery products. Researchers noticed that pumpkin flour has good ability to bind oil and absorb water. In addition, pumpkin powder is a suitable alternative emulsifier and can be possibly used in food mixes (Roongruangsri and Bronlund, 2016).

\section{Physical Measurements of Biscuit}

The study conducted a physical analysis of biscuits prepared by replacing wheat flour with pumpkin flour $(0 \%$, $3 \%, 6 \%, 9 \%$ and $12 \%$ ). The mean measurements of the physical analysis appear in table 3 and figures 5 and 6 .

Table 3. Physical Measurements of Biscuit Prepared with partial replacement of wheat flour with pumpkin pulp and peel flour

\begin{tabular}{|c|c|c|c|c|}
\hline \multirow{2}{*}{ Treatments } & \multicolumn{2}{c|}{ Physical Analyses (Reading+Standard Error) } \\
\cline { 3 - 5 } & $0 \%$ & Diameter $(\mathrm{mm})$ & Thickness $(\mathrm{mm})$ & Spread ratio $(\mathrm{D} / \mathrm{T})$ \\
\hline \multirow{3}{*}{ Control } & $3 \%$ & $40.667 \pm 0.05^{\mathrm{a}}$ & $5.997 \pm 0.005^{\mathrm{b}}$ & $6.783 \pm 0.015^{\mathrm{cd}}$ \\
\hline \multirow{3}{*}{$\begin{array}{l}\text { Biscuit prepared with } \\
\text { pumpkin pulp flour }\end{array}$} & $6 \%$ & $42.827 \pm 0.035^{\mathrm{a}}$ & $6.170 \pm 0.005^{\mathrm{b}}$ & $6.940 \pm 0.010^{\mathrm{c}}$ \\
\cline { 2 - 5 } & $\% 9$ & $40.827 \pm 0.030^{\mathrm{a}}$ & $4.997 \pm 0.000^{\mathrm{c}}$ & $8.407 \pm 0.010^{\mathrm{b}}$ \\
\cline { 2 - 5 } & $12 \%$ & $40.173 \pm 0.020^{\mathrm{c}}$ & $4.500 \pm 0.050^{\mathrm{d}}$ & $9.077 \pm 0.100^{\mathrm{a}}$ \\
\hline \multirow{3}{*}{$\begin{array}{l}\text { Biscuit prepared with } \\
\text { pumpkin peel flour }\end{array}$} & $3 \%$ & $40.827 \pm 0.055^{\mathrm{b}}$ & $4.330 \pm 0.085^{\mathrm{d}}$ & $9.287 \pm 0.180^{\mathrm{a}}$ \\
\cline { 2 - 5 } & $6 \%$ & $39.673 \pm 0.115^{\mathrm{d}}$ & $6.093 \pm 0.005^{\mathrm{b}}$ & $6.810 \pm 0.010^{\mathrm{cd}}$ \\
\cline { 2 - 5 } & $12 \%$ & $39.663 \pm 0.095^{\mathrm{d}}$ & $6.163 \pm 0.010^{\mathrm{b}}$ & $6.597 \pm 0.010^{\mathrm{cd}}$ \\
\cline { 2 - 5 } & $39.663 \pm 0.110^{\mathrm{d}}$ & $6.497 \pm 0.130^{\mathrm{a}}$ & $6.433 \pm 0.035^{\mathrm{de}}$ \\
\hline
\end{tabular}

All data are means of triplicate measurements. Means with different letters are significantly different $(\mathrm{P}<0.05)$. Control: $100 \%$ wheat flour/ $0 \%$ pumpkin flour. 3\%: $97 \%$ wheat flour/ $3 \%$ pumpkin pulp flour. 6\%: $94 \%$ wheat flour/ $6 \%$ pumpkin pulp flour. 9\%: $91 \%$ wheat flour/ 9\% pumpkin pulp flour. $12 \%: 88 \%$ wheat flour/ $12 \%$ pumpkin pulp flour. 3\%: $97 \%$ wheat flour/ $3 \%$ pumpkin peel flour. 6\%: 94\% wheat flour/ $6 \%$ pumpkin peel flour. 9\%: 91\% wheat flour/ 9\% pumpkin peel flour. $12 \%: 88 \%$ wheat flour/ $12 \%$ pumpkin peel flour.

A slight significant decrease $(\mathrm{P}<0.05)$ was found in mean of diameter and thickness of biscuit with increasing the ratio of pumpkin pulp flour compared to the standard treatment $(0 \%)$. The lowest averages were found to be $40.173 \mathrm{~mm}$ for diameter and $4.33 \mathrm{~mm}$ for thickness. While there was a significant increase $(\mathrm{P}<0.05)$ in spread ratio by increasing the replacement ratio of wheat flour with pumpkin pulp flour, 9.077 and 9.287 for the ratios $9 \%$ and $12 \%$ respectively.

Toan and Thuy (2018) found that the spread ratio increased from 6.49 to 9.27 in processed biscuits by increasing the ratio of replacing wheat flour with pumpkin pulp flour. The reason is that the continuous formation of gluten network is affected by protein of flour, which in turn increases the viscosity of the dough and stops the flow.

In biscuits prepared by replacing wheat flour with pumpkin peel flour, there was a significant decrease (P $<0.05)$ in the mean diameter and spread ratio with increasing replacement ratio, compared with the standard treatment. The lowest mean diameter and spread ratio were $39.663 \mathrm{~mm}$ and 6.110 respectively for the ratio $12 \%$. The mean thickness increased by increasing the replacement ratio compared with standard treatment and the pumpkin pulp biscuit, (Table 3). Differences in protein quality and water absorption may alter the flour ability to absorb water and may alter the spread ratio (Gurung et al., 2016). The spread ratio is an important characteristic in estimating the quality of flour used in the preparation of biscuits and its ability to rise (Adeola and Ohizua, 2018) the higher the value of the spread ratio, the product is highly desirable. Chauhan et al. (2016) found that spread ratio increased by increasing the replacement ratio of wheat flour with amaranth flour. Figures 7 and 8 illustrate samples of prepared biscuits. 


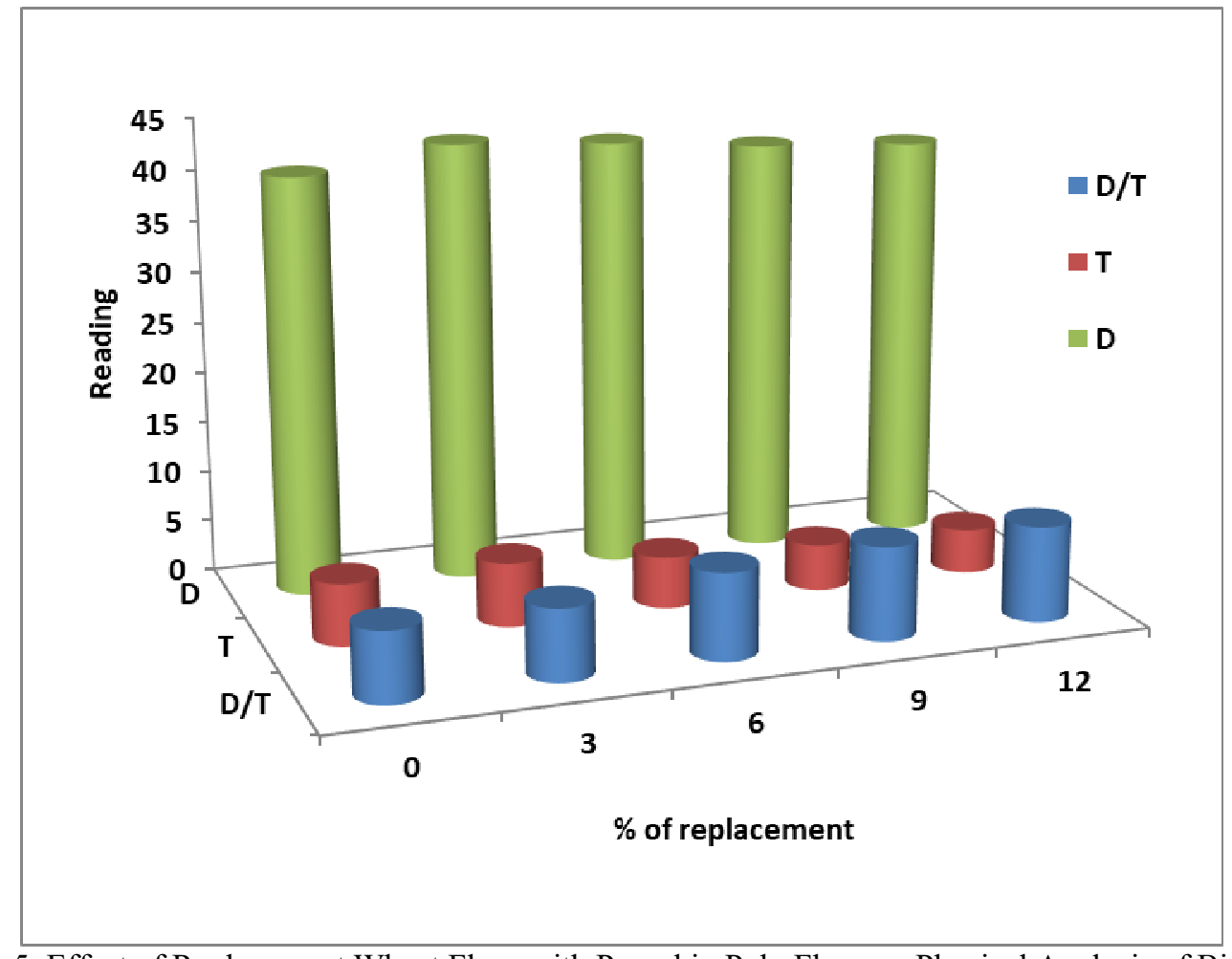

Fig. 5. Effect of Replacement Wheat Flour with Pumpkin Pulp Flour on Physical Analysis of Biscuit

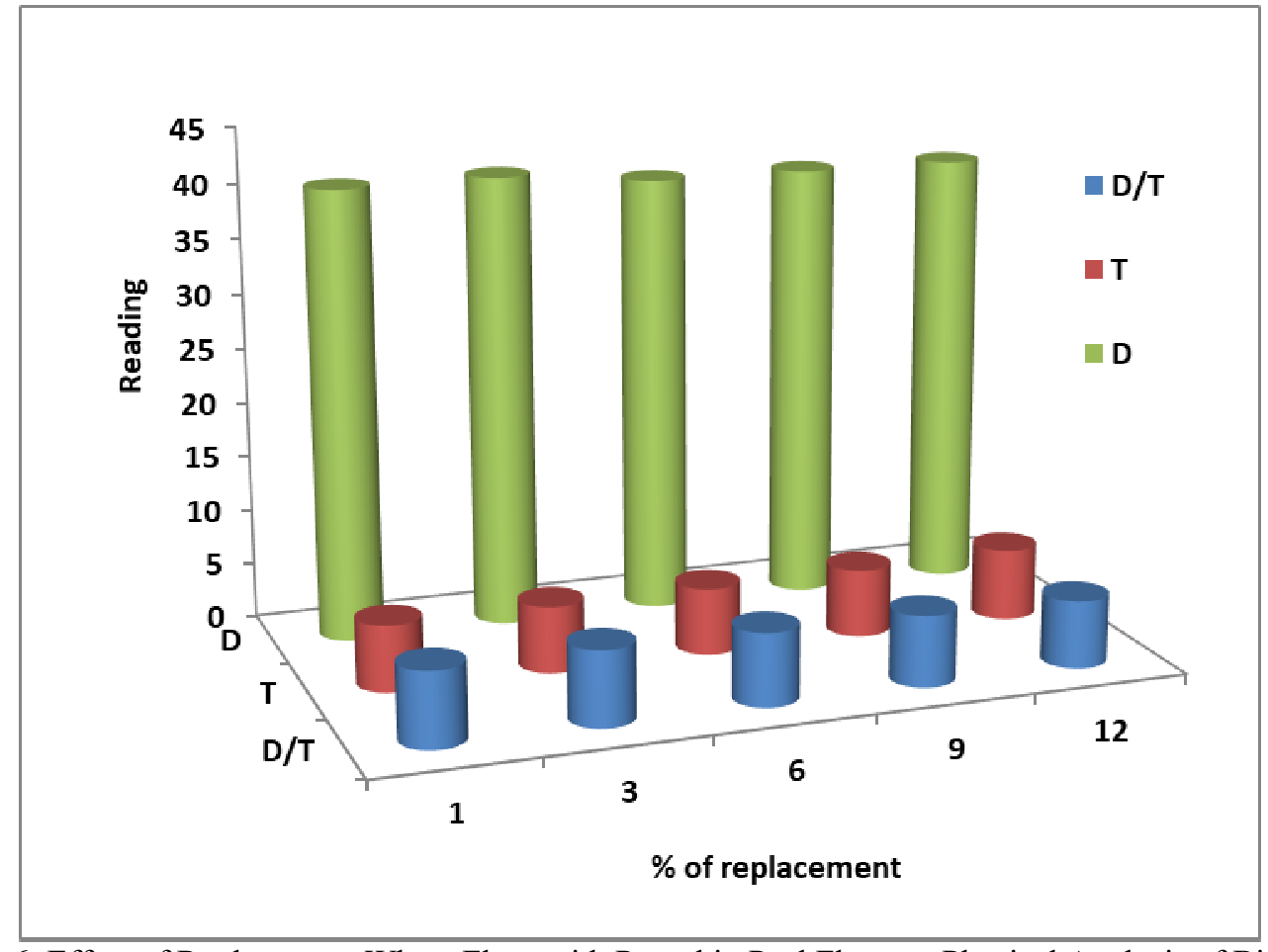

Fig. 6. Effect of Replacement Wheat Flour with Pumpkin Peel Flour on Physical Analysis of Biscuit 


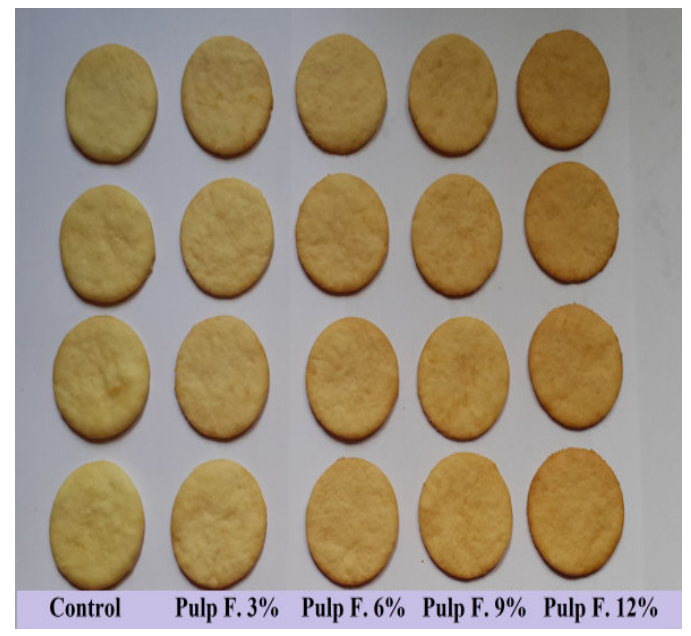

Fig. 7 Biscuit Prepared with Different Ratios of Pumpkin Pulp Flour

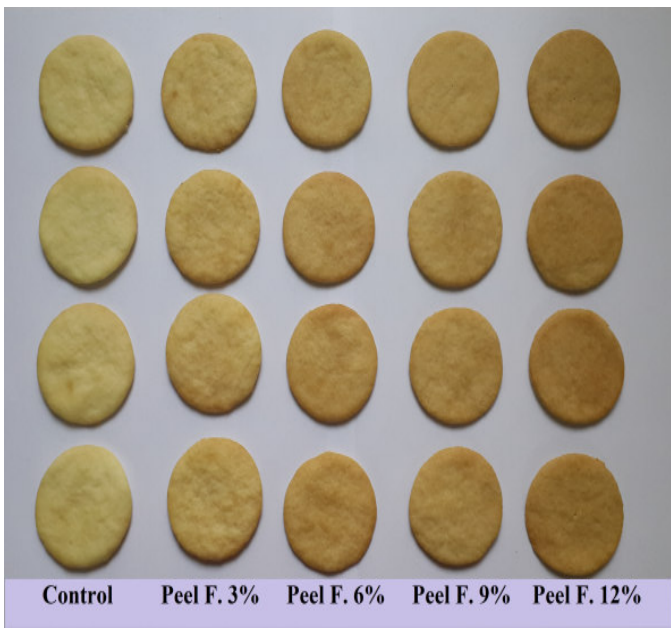

Fig. 8 Biscuit Prepared with Different

Ratios of Pumpkin Peel Flour

\section{Sensory Evaluation of Biscuits}

Table 4 shows mean values of the sensory evaluation of biscuits prepared from replacement of wheat flour with pumpkin flour (pulp and peel) $(0 \%, 3 \%, 6 \%, 9 \%$ and $12 \%)$. Significant differences $(\mathrm{P}<0.05)$ were recorded for sensory characteristics like appearance, color, odor, taste, texture and overall acceptability between biscuits. The study observed that biscuits prepared with a ratio of 3\% pumpkin pulp and pumpkin peel were the most acceptable for all sensory parameters. This was followed by biscuits with $6 \%$ pumpkin pulp flour. A significant decrease $(\mathrm{P}<0.05)$ was recorded for the mentioned sensory characteristics with increasing replacement of wheat flour with pumpkin pulp flour. A slight significant difference $(\mathrm{P}<0.05)$ was recorded for the sensory characteristics between biscuits prepared with different ratios of pumpkin peel flour, the ratio $3 \%$ gave high mean values $(8.95,8.85,8.60,8.55$ and 8.80$)$ for appearance, color, odor, taste, texture and overall acceptability respectively comparison with control treatment.

Appearance is one of the measures that characterize biscuit quality. For example, individual biscuits must be crispy and formed correctly (Oluwamukomi et al., 2011). Colour intensity of biscuits improved by increasing the replacement ratio of pumpkin pulp flour. The samples prepared with $12 \%$ pulp flour were the most telling in that they were less accepted by evaluators than with biscuit prepared with $3 \%$ pulp flour. Food color is one of the important quality parameters; this may indicate changes that occur in food quality because of processing, storage and other impacts, the yellow color attributed to carotene pigment in pumpkin fruit, the color value of the product is increased by the incorporation of pumpkin flour in batter (Usha et al., 2010 and El-Demery, 2011).

Table 4. Mean Values of Sensory Evaluation of Biscuits Fortified with Pumpkin Pulp and Peel Flour According to the 9-Points Hedonic Scale

\begin{tabular}{|c|c|c|c|c|c|c|c|}
\hline \multirow{2}{*}{\multicolumn{2}{|c|}{ Treatments }} & \multicolumn{2}{c|}{ Parameters } \\
\cline { 3 - 8 } & \multirow{2}{*}{$\begin{array}{c}\text { Appearance } \\
\text { Color }\end{array}$} & Odor & Taste & Texture & $\begin{array}{c}\text { Overall } \\
\text { acceptability }\end{array}$ \\
\hline Control & $0 \%$ & $8.90^{\mathrm{abc}}$ & $9.25^{\mathrm{a}}$ & $9.00^{\mathrm{a}}$ & $8.90^{\mathrm{a}}$ & $8.90^{\mathrm{a}}$ & $9.05^{\mathrm{ab}}$ \\
\hline \multirow{2}{*}{$\begin{array}{c}\text { Biscuit prepared } \\
\text { with pumpkin pulp } \\
\text { flour }\end{array}$} & $3 \%$ & $9.20^{\mathrm{a}}$ & $8.90^{\mathrm{ab}}$ & $9.15^{\mathrm{a}}$ & $8.90^{\mathrm{a}}$ & $8.85^{\mathrm{a}}$ & $9.15^{\mathrm{a}}$ \\
\cline { 2 - 8 } & $6 \%$ & $8.55^{\mathrm{abcd}}$ & $8.70^{\mathrm{ab}}$ & $8.50^{\mathrm{ab}}$ & $8.30^{\mathrm{abc}}$ & $8.40^{\mathrm{abc}}$ & $8.75^{\mathrm{ab}}$ \\
\cline { 2 - 8 } & $\% 9$ & $8.55^{\mathrm{abcd}}$ & $8.20^{\mathrm{bc}}$ & $7.95^{\mathrm{bc}}$ & $8.20^{\mathrm{abc}}$ & $8.35^{\mathrm{abc}}$ & $8.40^{\mathrm{bc}}$ \\
\cline { 2 - 8 } & $12 \%$ & $7.80^{\mathrm{cd}}$ & $8.00^{\mathrm{bc}}$ & $7.80^{\mathrm{bc}}$ & $7.95^{\mathrm{bc}}$ & $7.80^{\mathrm{abc}}$ & $8.05^{\mathrm{cd}}$ \\
\hline \multirow{3}{*}{$\begin{array}{c}\text { Biscuit prepared } \\
\text { with pumpkin peel } \\
\text { flour }\end{array}$} & $3 \%$ & $8.95^{\mathrm{ab}}$ & $8.85^{\mathrm{ab}}$ & $8.75^{\mathrm{ab}}$ & $8.60^{\mathrm{ab}}$ & $8.55^{\mathrm{ab}}$ & $8.80^{\mathrm{ab}}$ \\
\cline { 2 - 8 } & $6 \%$ & $8.85^{\mathrm{abc}}$ & $8.75^{\mathrm{ab}}$ & $8.40^{\mathrm{ab}}$ & $8.30^{\mathrm{abc}}$ & $7.90^{\mathrm{abc}}$ & $8.60^{\mathrm{abc}}$ \\
\cline { 2 - 8 } & $9 \%$ & $8.00^{\mathrm{bcd}}$ & $8.00^{\mathrm{bc}}$ & $7.40^{\mathrm{c}}$ & $7.50^{\mathrm{cd}}$ & $7.30^{\mathrm{bc}}$ & $7.75^{\mathrm{de}}$ \\
\cline { 2 - 8 } & $12 \%$ & $7.60^{\mathrm{d}}$ & $7.70^{\mathrm{c}}$ & $7.10^{\mathrm{c}}$ & $6.95^{\mathrm{d}}$ & $7.05^{\mathrm{c}}$ & $7.30^{\mathrm{e}}$ \\
\hline
\end{tabular}

All data are means of ten values. Means with different letters are significantly different $(\mathrm{P}<0.05)$.

The color of biscuits prepared with peel flour tends to be greenish-yellow with increasing the replacement ratio. Color in biscuits is due to the presence of carotene and chlorophyll pigments in fruit peels. The study noted that the results of sensory evaluation of the control treatment $(0 \%$ pumpkin flour) were close to the results of samples with 3\% replacement for both pulp and peel flour. Changes occurring in carotenoids and other dyes affected the color and quality of the product may result from temperature and oxidation process during the 
drying stage. Similarly, the hot drying period may cause the loss of pigment as result of degradation that happens due to heat (Roongruangsri and Bronlund, 2016). Sensory evaluation of odor decreased significantly with the increase of the replacement ratio beyond the ratio 3\% and 6\% (pulp flour) and $6 \%$ (peel flour). This may be due to the strong aroma and flavor of pumpkin tested in high concentrations. This analysis is supported by See et al. (2007) when bread was using different concentrations of pumpkin flour. A strong odor of pumpkin increased noticeably at $5 \%$ and $10 \%$ levels of pulp flour.

The texture of biscuits produced satisfied the evaluators initially, and then satisfaction decreased significantly with increasing the replacement ratio. Biscuits became hard with the increase of the replacement ratio. This result agreed with findings of Kulkarni and Joshi (2013), who produced biscuit with replacement ratios $2.5 \%, 5 \%, 7 \%$ and $10 \%$ pumpkin flour. The flavor decreased because increases resulted in an oily flavor. Nyam et al. (2013) prepared bread with different replacement ratios of pumpkin peel and pulp flour $(0 \%, 5 \%$ and $10 \%$ ). They found that products of 5\% were the most acceptable and had a strong aroma and soft texture because of good ability of peel flour to hold water better than wheat flour. A $6 \%$ replacement ratio of peel flour gave the biscuits a smell like tea because pumpkin peel contains catechins, a flavonoid compound presence in tea and cacao beans (Yilmaz, 2007).

The mean values of overall acceptability of biscuits showed that biscuits with replacement ratio $3 \%$ of pulp and peel flour were the highest, followed by standard treatment and other treatments.

\section{References}

1. AACC (1976). Approved Methods of the American Association of Cereal Chemists, $7^{\text {th }}$ Edition. USA.

2. AACC (2000). International Approved Methods of the American Association of Cereal Chemists. $10^{\text {th }}$ Edition, AACC International, Saint Paul, USA.

3. Adeola, A. A. and Ohizua, E. R. (2018). Physical, Chemical, and Sensory Properties of Biscuits Prepared from Four Blends of Unripe Cooking Banana, Pigeon Pea, and Sweet Potato, Food Science and Nutrition: $1-9$.

4. AOAC (1975). Official Methods of Analysis. Association of Official Analytical Chemists $13^{\text {th }}$ Edition. Washington, D.C.

5. AOAC (1984). Association of Official Analytical Chemists. Official Methods of Analysis, $14^{\text {th }}$ Edition, Washington, D.C, USA.P 567.

6. Appiah, F.; Oduro, I. and Ellis, W. O. (2011). Functional Properties of Artocarpus altilis Pulp Flour as Affected by Fermentation, Agriculture and Biology Journal of North America, (5): 773-779.

7. Batista, J. E. R.; Braga, L. P.; De Oliveira, R. C.; Silva, E. P. and Damiani, C. (2018). Partial Replacement of Wheat Flour by Pumpkin Seed Flour in the Production of Cupcakes Filled with Carob. Food Science and Technology, 38(2): 250-254.

8. Beuchat, L. R. (1977). Functional and Electrophoretic Characteristics of Succinylated Peanut Flour Proteins. Journal of Agricultural and Food Chemistry, 25:258-261.

9. Cerniauskiene, J.; Kulaitiene, J.; Danilcenko, H.; Jariene, E. and Jukneviciene, E. (2014). Pumpkin Fruit Flour as a Source for Food Enrichment in Dietary Fiber, Notulae Botanicae Horti Agrobotanici ClujNapoca, 42(1):19-23.

10. Chauhan, A.; Saxena, D. C. and Singh, S. (2016). Physical, textural, and sensory characteristics of wheat and amaranth flour blend cookies, Cogent Food \& Agriculture, 2: 1-8.

11. El-Demery, M. E. (2011). Evaluation of Physico-Chemical Properties of Toast Breads Fortified with Pumpkin (Cucurbita moschata) Flour, The $6^{\text {th }}$ Arab and $3^{\text {rd }}$ International Annual Scientific Conference on: Development of Higher Specific Education Programs in Egypt and the Arab World in the Light of Knowledge Era Requirements: 2146-2161.

12. Fagbemi, T. N.; Oshodi, N. A. and Ipinmoroti, K. O. (2005). Effect of Processing on the Functional Properties of full fat and Defatted Fluted Pumpkin (Telfairia occidentalis) Seed Flours. Journal of Food Technology, 3 (3): 370-377.

13. Gurung, B.; Ojha, P. and Subba, D. (2016). Effect of Mixing Pumpkin Puree with Wheat Flour on Physical, Nutritional and Sensory Characteristics of Biscuit, Journal of Food Science and Technology, Nepal, 9: 8589.

14. Kulkarni, A. S. and Joshi, D. C. (2013). Effect of Replacement of Wheat Flour with Pumpkin Powder on Textural and Sensory Qualities of Biscuit, International Food Research Journal 20(2): 587-591.

15. Mishra, N. and Chandra, R. (2012). Development of Functional Biscuit from Soy Flour and Rice Bran, International Journal of Agricultural and Food Science, 2(1): 14-20.

16. Mujaffar, S. and Ramsumair, S. (2019). Fluidized Bed Drying of Pumpkin (Cucurbita sp.) Seeds. Foods, 8 (147): $1: 13$.

17. Nawirska-Olszańska, A.; Biesiada, A.; Anna Sokół-Łętowska, A. and Kucharska, A. Z. (2011). Content of Bioactive Compounds and Antioxidant Capacity of Pumpkin Puree Enriched with Japanese Quince, 
Cornelian Cherry, Strawberry and Apples, Acta Scientiarum Polonorum, Technologia Alimentaria, 10(1): 51-60.

18. Nyam, K. L.; Lau, M. and Tan, C. P. (2013). Fiber from Pumpkin (Cucurbita pepo L.) Seeds and Rinds: Physico-chemical Properties, Antioxidant Capacity and Application as Bakery Product Ingredients, Malaysian Journal of Nutrition, 19 (1): 99-109.

19. Oluwamukomi, M. O.; Oluwalana, I. B. and Akinbowale, O. F. (2011). Physicochemical and Sensory Properties of Wheatcassava Composite Biscuit Enriched with Soy Flour, African Journal of Food Science, 5 (2): $50-56$.

20. Pasha, I; Bashir Khan, Q. A.; Butt, M. S. and Saeed, M. (2013). Rheological and Functional Properties of Pumpkin Wheat Composite Flour, PAK. J. FOOD SCI., 23(2), 2013: 100-104.

21. Păucean, A. and Man, S. (2014). Physico-chemical and Sensory Evaluations of Wheat Bread with Pumpkin (Cucurbita maxima) Pulp Incorporated, Journal of Agroalimentary Processes and Technologies, 20 (1): 2632.

22. Pearson, D. (1970). The Chemical Analysis of Food $6^{\text {th }}$ Edition. Chemical Publishing Company, Inc., New York.

23. Pongjanta, J.; Naulbunrang, A.; Kawngdang, S.; Manon, T.; and Thepjaikat, T. (2006). Utilization of Pumpkin Powder in Bakery Products, Songklanakarin J. Sci. Technol. 28 (Suppl.1): 71-79.

24. Pratyush, K.; Masih, D. and Sonkar, C. (2015). Development and Quality Evaluation of Pumpkin Powder Fortified Cookies, International Journal of Science, Engineering and Technology, 3 (4): 1034-1038.

25. Roongruangsri, W.; Bronlund, J. E. (2016). Effect of Air-drying Temperature on Physico-chemical, Powder Properties and Sorption Characteristics of Pumpkin Powders. Food Research International, 23: 962-972.

26. Sathiya Mala, K.; Aathira, P.; Anjali, E. K.; Srinivasulu, K. and Sulochanamma, G. (2018). Effect of Pumpkin Powder Incorporation on the Physico-Chemical, Sensory and Nutritional Characteristics of Wheat Flour Muffins. International Food Research Journal 25(3): 1081-1087.

27. See, E. F.; Wan Nadiah, W.A. and Noor Aziah, A.A. (2007). Physico - Chemical and Sensory Evaluation of Breads Supplemented with Pumpkin Flour, ASEAN Food Journal 14 (2): 123-130.

28. Staichok, A. C. B.; Mendonça, K. R. B.; Santos, P. G. A.; Garcia, L. G. C. G. and Damiani, C. (2016). Pumpkin Peel Flour (Cucurbita máxima L.) - Characterization and Technological Applicability, Journal of Food and Nutrition Research, 4 (5): 327-333.

29. Steel, R. G. D.; Torrie, J. H. and Dickey, D. A. (1996). Principles and Procedures of Statistics. A biometrical Approach. $3^{\text {rd }}$ ed. McGraw Hill Book Company Inc, New York, USA.

30. Toan, N. V. and Thuy, N. T. T. (2018). Production of High-quality Flour and the Made Biscuits from Pumpkin. International Journal of Food Science and Nutrition, 3 (5): 157-166.

31. Usha R.; Lakshmi M. and Ranjani M. (2010). Nutritional, sensory and Physical Analysis of Pumpkin Flour Incorporated into Weaning Mix, Malaysian Journal of Nutrition, 16(3): 379-387.

32. Verma, S.; Kumar, N. and Sharma, P. K. (2014). Extraction and Evaluation of Trigonella Foenum graecum Linn and Linum usitatissimum Seed Mucilage, Global Journal of Pharmacology 8 (4): 510-514.

33. Watts, B. M.; Ylimaki, L. E.; Jeffery, L. E. and Elias, L. G. (1989). Basic Sensory Methods for Food Evaluation. IDRC, Canada.

34. Yilmaz, Y. (2006). Review: Novel Uses of Catechins in Foods, Food Science Technology, 17: 64-67. 